Jurnal Ekonomi Pembangunan, 16 (1), Juni 2015, 46-60

\title{
Causality Between Urban Concentration and Environmental Quality
}

\author{
Amin Pujiati, Dyah Maya Nihayah, Prasetyo Ari Bowo \\ Faculty of Economics, Universitas Negeri Semarang \\ Gedung C3 Lantai 1 Kampus Sekaran Gunungpati Semarang 50229, Indonesia \\ E-mail: amin.pujiati@gmail.com
}

Received: March 2015; Accepted: May 2015

\begin{abstract}
Population is concentrated in urban areas can cause the external diseconomies on environment if it exceeds the carrying capacity of the space and the urban economy. Otherwise the quality of the environment is getting better, led to the concentration of population in urban areas are increasingly high. This study aims to analyze the relationship of causality between the urban concentration and environmental quality in urban agglomeration areas. The data used in the study of secondary data obtained from the Central Bureau of statistics and the City Government from 2000 to 2013. The analytical method used is the Granger causality and descriptive. Granger causality study results showed no pattern of reciprocal causality, between urban concentration and the quality of the environment, but there unidirectional relationship between the urban concentration and environmental quality. This means that increasing urban concentration led to decreased environmental quality.
\end{abstract}

Keywords: unemployment, concentration of population, agglomeration, Granger causality

JEL Classification: C23, R10, R11

\section{Kausalitas Antara Konsentrasi Perkotaan dan Kualitas Lingkungan}

\begin{abstract}
Abstrak
Penduduk yang berkonsentrasi di perkotaan dapat menyebabkan external diseconomies terhadap lingkungan, jika melebihi daya dukung ruang dan ekonomi perkotaan. Sebaliknya kualitas lingkungan yang semakin baik menyebabkan konsentrasi penduduk di perkotaan semakin tinggi. Studi ini bertujuan menguji hubungan kausalitas antara konsentrasi perkotaan dan kualitas lingkungan di wilayah aglomerasi perkotaan Semarang. Data yang digunakan dalam penelitian ini data sekunder yang diperoleh dari Badan Pusat Statistik dan Pemerintah kota dari tahun 20002013. Metode analisis yang digunakan adalah kausalitas Granger dan deskriptif. Hasil studi kausalitas Granger menunjukkan tidak ada pola hubungan kausalitas timbal balik antara konsentrasi perkotaan dan kualitas lingkungan namun terjadi hubungan searah antara konsentrasi perkotaan dan kualitas lingkungan. Hal ini berarti konsentrasi perkotaan yang meningkat menyebabkan kualitas lingkungan semakin menurun.
\end{abstract}

Kata kunci: pengangguran, konsentrasi populasi, aglomerasi, kausalitas Granger Klasifikasi JEL: C23, R10, R11

\section{Pendahuluan}

Laju pertumbuhan penduduk Indonesia menunjukkan kecenderungan bertempat tinggal di daerah perkotaan. Setiap tahun manusia berpindah (migrasi) dari daerah pedesaan ke perkotaan. Perkembangan penduduk kota bisa dilihat dari tingkat urbanisasi dan konsentrasi perkotaan. Tingkat urbanisasi menunjukkan bagian dari jumlah penduduk total yang tinggal di wilayah kota (urban areas). Konsentrasi perkotaan menunjukkan perbandingan antara jumlah penduduk perkotaan di wilayah kota tertentu dengan jumlah total penduduk perko- 


\section{Jurnal Ekonomi Pembangunan, 16 (1), Juni 2015, 46-60}

taan di wilayah yang lebih luas (Salenussa, 2009)

Menurut Todaro dan Smith (2006 ) pertumbuhan penduduk perkotaan yang terlalu cepat di negara-negara berkembang tergantung bagaimana suatu negara merumuskan kebijakan pembangunan yang memiliki dampak terhadap pertumbuhan kota. Strategi pembangunan yang lebih mengutamakan modernisasi industri, kecanggihan teknologi, dan pertumbuhan metropolis, telah menciptakan ketimpangan geografis dalam penyebaran kesempatan atau peluang-peluang ekonomi, sekaligus menjadi penyebab utama perpindahan secara besar-besaran penduduk desa ke kota-kota yang terus menerus. Demikian juga hasil penelitian dari Qasim, M et al. (2014).

Daya tarik kota dan perkembangannya, menjadikan pertumbuhan kota sulit dikendalikan. Pertumbuhan kota mempunyai nilai positif asalkan mereka yang melakukan perpindahan ke kota tersebut memiliki keterampilan tertentu dan dapat ditampung dalam kegiatan ekonomi kota atau bahkan menciptakan kerja yang layak di kota. Apabila tidak, hal ini hanya menyebabkan external diseconomies, baik terhadap lingkungan, sosial, ekonomi, politik dan keamanan.

Berkaitan dengan lingkungan, pertumbuhan kota yang dilihat dari bertambahnya penduduk kota sering dituduh sebagai penyebab degradasi lingkungan ( $\mathrm{Li}, \mathrm{S}$ dan Yong $\mathrm{Ma}$ (2014). Pertumbuhan kota berdampak terhadap kerusakan lingkungan dalam jangka panjang. Kesimpulan ini didukung oleh Lakshmana, C.M (2013), Coles et al. (2010), Jiang dan Harde (2009) dan Cho et al. (2007).

Konsentrasi perkotaan yang tinggi mempengaruhi kualitas lingkungan sesuai dengan fenomena yang ada di Indonesia.Berdasarkan Sensus Penduduk 2010, pertumbuhan penduduk Indonesia masih cenderung terkonsentrasi di Pulau Jawa yaitu sebesar 57,49 persen.. Terkonsentrasinya penduduk Indonesia di Pulau Jawa, jika dikaitkan dengan masalah lingkungan terdapat korelasi antara keduanya. Pulau yang padat penduduknya pada umumnya kualitas lingkungannya rendah. Berdasarkan penghitungan indeks kualitas lingkungan hidup berdasarkan pulau yang dilakukan oleh Kementerian Lingkungan Hidup/KLH (2012), Pulau Jawa berada pada posisi terendah yaitu 57,06 itu artinya kualitas lingkungan hidup di Pulau Jawa paling jelek dibandingkan pulaupulau lain di Indonesia (Tabel 1)

Tabel 1. Indeks Kualitas Lingkungan Hidup (IKLH) Menurut Pulau Tahun 2011

\begin{tabular}{clc}
\hline Ranking & \multicolumn{1}{c}{ Kepulauan } & IKLH \\
\hline 1 & Sulawesi & 76,86 \\
2 & Bali dan Nusa Tenggara & 71,94 \\
3 & Sumatera & 71,47 \\
4 & Maluku dan Papua & 70,91 \\
5 & Kalimantan & 68,89 \\
6 & Jawa & 57,06 \\
& Indonesia & 60,25 \\
\hline
\end{tabular}

Sumber: Kementerian Lingkungan Hidup (KLH), 2012

Hasil penelitian yang berkaitan dengan dampak konsentrasi perkotaan terhadap lingkungan berbeda dengan The Economist Intelligence Unit (2011), Thomas dan Belt (1997), Dasgupta (1995), Cropper dan Griffiths (1994) bahwa tidak selalu kota yang penduduknya padat kualitas lingkungan jelek dan sebaliknya. Dengan kata lain tidak selalu konsentrasi perkotaan berdampak negatif terhadap lingkungan. Lebih lanjut Pujiati, A dan J.J Sarungu (2012) berdasarkan hasil penelitiannya menghasilkan kesimpulan lingkungan berpengaruh positif terhadap pertumbuhan kota. Perbedaan hasil penelitian (research gap) tentang hubungan antara pertumbuhan kota dan kualitas lingkungan tersebut yang menjelaskan di satu sisi pertumbuhan kota berpengaruh terhadap kualitas lingkungan dan di satu sisi kualitas lingkungan berpengaruh terhadap pertumbuhan, perlu dilakukan penelitian lebih lanjut untuk melihat hubungan sebab akibat antara pertumbuhan kota yang diukur dengan konsentrasi perkotaan dan kualitas lingkungan. Bentuk hubungan kausalitas antara konsentrasi perkotaan dan kualitas lingkungan akan berpengaruh terhadap perumusan kebijakan perkotaan. 


\section{Jurnal Ekonomi Pembangunan, 16 (1), Juni 2015, 46-60}

Penelitian ini fokus pada kausalitas antara konsentrasi perkotaan dan lingkungan dengan objek penelitian di wilayah aglomerasi perkotaan Semarang. Pertimbangan dipilihnya aglomerasi Semarang adalah wilayah aglomerasi tersebut terletak di Pulau Jawa, Pulau tempat terkonsentrasinya penduduk Indonesia. Pertimbangan lainnya, wilayah aglomerasi Semarang (Provinsi Jawa Tengah) adalah satu-satunya wilayah yang berdasarkan pemeringkatan indeks kualitas lingkungan di Pulau Jawa dari tahun 2009-2011 semakin menurun nilai kualitas lingkungannnya (KLH, 2012) yang bisa dilihat padaTabel 2. Berdasarkan perbedaan penelitian (research gap) yang sudah dijelaskan, maka tujuan studi ini adalah untuk menguji hubungan kausalitas antara konsentrasi perkotaan dan kualitas lingkungan.

Tabel 2. IKLH menurut Provinsi di Pulau Jawa. Tahun 2009-2011

\begin{tabular}{lccc}
\hline Provinsi & \multicolumn{3}{c}{ Tahun } \\
\cline { 2 - 4 } & 2009 & 2010 & 2011 \\
\hline DIY & 53,52 & 71,91 & 68,89 \\
Jawa Timur & 59,01 & 49,49 & 54,49 \\
Jawa Barat & 49,69 & 53,44 & 50,90 \\
Jawa Tengah & 55,40 & 50,48 & 49,82 \\
Banten & 50,86 & 48,98 & 48,98 \\
DKI & 41,73 & 41,81 & 41,31 \\
\hline
\end{tabular}

Sumber : Kementerian Lingkungan Hidup (KLH), 2012

\section{Metode Penelitian}

Penelitian ini dilakukan di wilayah aglomerasi perkotaan Semarang yang terdiri dari 7 kabupaten/kota. Wilayah aglomerasi Semarang terdiri: Kota Semarang, Kabupaten Semarang, Kabupaten Kendal, Kabupaten Demak, Kota Salatiga, Kabupaten Demak, Kabupaten Grobogan, Kabupaten Temanggung. Data sekunder diperoleh dari Badan Pusat Statistik (BPS) dan Pemerintah kota di wilayah aglomerasi perkotaan Semarang. Penelitian ini menggunakan data time series dari tahun 2000 - 2013.

Adapun variabel yang digunakan dalam penelitian ini adalah: 1) konsentrasi perkotaan
(IP) yang diukur dengan indeks primasi seperti yang dilakukan oleh Ades dan Glaeser (1995), Bourne (1996), Moomaw dan Shatter (1996), Henderson (2002), Moomaw dan Alwasabi (2004, 2007) yang diukur dengan indeks primacy yaitu konsentrasi penduduk perkotaan di kabupaten/ kota pada tahun tertentu dibagi penduduk perkotaan seluruh wilayah aglomerasi, 2) kualitas lingkungan yang diukur dengan indeks kualitas lingkungan (IK). Pengukuran kualitas lingkungan pada umumnya dilakukan secara parsial berdasarkan media, yaitu air, udara dan lahan (KLH, 2010). Berdasarkan pengukuran kualitas lingkungan yang dilakukan oleh KLH dan laporan status lingkungan hidup, maka dalam penelitian ini kualitas lingkungan hanya diukur berdasarkan media lahan dan air tanpa media udara.

Meskipun dalam penelitian ini pengukuran kualitas lingkungan melalui media udara tidak dilakukan secara langsung karena keterbatasan data media udara di tingkat kabupaten/kota, namun tidak berarti pengukuran kualitas lingkungan dari media udara tidak terukur sama sekali. Pengukuran ini secara tidak langsung sudah dapat diwakili oleh media lahan dan air.

Alasan yang dapat dijelaskan pengukuran media udara secara tidak langsung melalui media lahan adalah lahan sawah, tegalan, hutan rakyat yang pada dasarnya berisi tanaman/pohon tidak hanya berperan sebagai penghasil pangan, tetapi juga memiliki peran lain yang manfaatnya dapat dinilai dari segi lingkungan. Manfaat dari segi lingkungan adalah dalam hal pengendalian pencemaran udara dan penghasil oksigen melalui proses fotosintesis.

Fotesintesis tumbuhan adalah suatu proses alamiah yang terjadi di dalam daun-daunan tumbuhan dimana terjadi penyerapan carbon dioxide (CO2) dan dihasilkannya gas oksigen yang ditambahkan ke udara. Penyerapan $\mathrm{CO} 2$ dari udara oleh tumbuhan untuk disimpan (carbon sequestration) memberi andil dalam mengurangi pencemar $\mathrm{CO} 2$ di udara. Karbon dari CO2 ini sebagai bahan baku untuk menghasilkan jaringan tumbuhan/kayu. Hal ini didukung oleh hasil penelitian Adita, B.R dan 


\section{Jurnal Ekonomi Pembangunan, 16 (1), Juni 2015, 46-60}

Ratni, N (2012), Rohman, A.S (2009) dan Setiyanto, dkk (2003).

Pengukuran kualitas lingkungan dari media udara secara tidak langsung juga dapat melalui media air yang digunakan dalam penelitian ini khususnya curah hujan. Menurut Murdiyarso dalam Saputra (2008) curah hujan dapat menghilangkan polutan yang ada di atmosfer sebelum terjadi proses dispersi, polutan tercuci di udara melalui dua cara yaitu polutan terkondensasi yang terbentuk sebagai air hujan dan polutan yang akan langsung tercuci oleh air hujan untuk kemudian diendapkan di permukaan. Melalui media lahan dan air yang digunakan dalam penelitian ini, diharapkan kualitas lingkungan melalui media udara secara tidak langsung sudah dapat terukur.

Media lahan diukur dengan luas lahan budidaya (LNB) seperti yang digunakan oleh Van dijk dan Mingshun (2005), Lee dan Huang (2007), Wahyudi (2009). Lahan budi daya dalam penelitian ini terdiri dari lahan sawah, tegalan dan hutan rakyat. Media air sebagai indikator kualitas lingkungan dapat digambarkan dengan kuantitas atau ketersediaan (volume) dan kualitas air. Kuantitas air (ketersediaan) berhubungan dengan berapa banyak air yang dapat dimanfaatkan dengan kebutuhannya, sedangkan kualitas air berhubungan dengan kelayakan pemanfaatannya untuk berbagai kebutuhan. Ketersediaan sumber daya air dapat juga ditandai dengan curah hujan (KLH, 2010). Dengan mempertimbangkan kuantitas dan kualitas air, maka dalam penelitian ini kualitas lingkungan berdasarkan media air diukur dengan banyaknya produksi air bersih per kapita (AB) yang dapat diproduksi oleh Perusahaan Daerah Air Minum seperti yang digunakan oleh Sherbinin (2003), dan rata-rata curah hujan $(\mathrm{CH})$ seperti yang digunakan oleh Mc. Granahan (2011).IK diukur dari rata-rata indeks tunggal lahan budidaya (LNB), banyaknya produksi air bersih $(\mathrm{AB})$, rata-rata curah hujan $(\mathrm{CH})$. Komponen pembentuk kualitas lingkungan dihitung indeks tunggal metode minimum-maksimum. Indeks kualitas lingkungan merupakan ratarata dari komponen pembentuk kualitas lingkungan.

Metode pengumpulan data dalam peneli- tian ini adalah dokumentasi, yaitu salah satu metode pengumpulan data yang diperoleh dari dokumen/tulisan yang disusun oleh badan/ pihak yang dapat dipertanggungjawabkan kevaliditasannya (Kuncoro, 2003), dalam hal ini dokumen tersebut adalah laporan periodik yang dikeluarkan oleh Badan Pusat Statistik (BPS). Untuk menguji hubungan kausalitas antara konsentrasi perkotaan dan kualitas lingkungan digunakan Uji kausalitas Granger. Uji Kausalitas dilakukan karena ada tiga kemungkinan arah kausalitas. Pertama, variabel X menyebabkan variabel Y, Kedua, variabel Y menyebabkan variabel X, Ketiga, hubungan timbal balik variabel $\mathrm{X}$ menyebabkan variabel $\mathrm{Y}$ dan pada saat yang sama variabel $\mathrm{Y}$ menyebabkan variabel X (Kuncoro, 2001). Model dasar penelitian yang digunakan dapat diformulasikan sebagai berikut:

$\mathrm{Yt}=\Sigma \mathrm{aiY}_{\mathrm{t}-\mathrm{i}}+\Sigma \mathrm{bjj}_{\mathrm{t}-\mathrm{j}}+\mathrm{vt}$

$\mathrm{Xt}_{\mathrm{t}}=\Sigma c i \mathrm{X}_{\mathrm{t}-\mathrm{i}}+\Sigma \mathrm{dj} \mathrm{Y}_{\mathrm{t}-\mathrm{j}}+\mu \mathrm{t}$

di mana: $\mathbf{Y}$ adalah konsentrasi perkotaan; $\mathbf{X}$ adalah kualitas lingkungan; a,b,c,d adalah koefisien; $\mathbf{t}$ adalah waktu; $\mathbf{i}, \mathbf{j}$ adalah $1,2,3 \ldots \mathrm{k} ; \mathbf{v}, \mathbf{p}$ adalah error

\section{Hasil dan Pembahasan}

\subsection{Konsentrasi Perkotaan}

Konsentrasi perkotaan dalam penelitian ini diukur dengan menggunakan indeks primasi yaitu jumlah penduduk perkotaan di satu kabupaten/kota dibagi dengan jumlah total penduduk perkotaan di wilayah aglomerasinya. Hasil penghitungan indeks primasi di wilayah aglomerasi perkotaan Semarang dilihat pada Lampiran. Pada lampiran terlihat bahwa indeks primasi Kabupaten/Kota di wilayah aglomerasi perkotaan Semarang dari tahun 2000-2013 relatif tetap. Rata-rata indeks primasi Kabupaten/Kota di wilayah aglomerasi Semarang terbesar adalah Kota Semarang sebagai kota inti (core) yaitu 0,49. Angka indeks primasi Kota Semarang jauh di atas rata-rata angka 


\section{Jurnal Ekonomi Pembangunan, 16 (1), Juni 2015, 46-60}

indeks primasi wilayah aglomerasi perkotaan Semarang yang hanya 0,28. Hal ini menunjukkan ada kecenderungan terkonsentrasinya penduduk di wilayah aglomerasi perkotaan Semarang di Kota Semarang. Kecenderungan menguatnya peran kota inti mengingat Kota Semarang sebagai Ibukota Provinsi Jawa Tengah yang tentunya banyak fasilitas-fasilitas perkotaan yang menarik. Fasilitas- fasilitas ekonomi dan sosial yang tersedia seperti fasilitas pendidikan, kesehatan, ekonomi dan obyek wisata di Kota Semarang lebih banyak dibandingkan fasilitas-fasilitas perkotaan Kabupaten/Kota di wilayah aglomerasi perkotaan Semarang lainnya.Kecenderungan memusatnya pertumbuhan kota di daerah kota inti juga bisa terlihat dalam Gambar 1. Kota semarang indeks primasinya jauh berada dia atas indeks primasi kabupaten/kota lainnya. Kecenderungan yang memusat di kota inti, dalam jangka panjang tidak menutup kemungkinan menimbulkan beberapa masalah perkotaan jika kapasitas kota sudah tidak dapat mencukupi kebutuhan penduduknya seperti pemukiman, pengangguran, transportasi, kemiskinan. Untuk itu diperlukan kerjasama manajemen perkotaan yang saling bersinergi dengan pemerintah kota sekitarnya. Kerjasama ini diharapkan di satu sisi, pertumbuhan kota inti dalam jangka panjang tidak menimbulkan masalah baru, di sisi lain kota sekitarnya akan memperoleh manfaat spillover effect sehingga pembangunan antar wilayah semakin merata.

\subsection{Kualitas Lingkungan}

Pengukuran kualitas lingkungan dalam penelitian ini dengan menggunakan media lahan dan air. Alasan penggunaan kedua media yang sudah dijelaskan pada metode penelitian juga sejalan dengan laporan status lingkungan hidup tahun 2010 oleh KLH tentang urutan jenis degradasi yang membutuhkan biaya besar. Jenis degradasi tersebut adalah perubahan iklim, air bersih dan sanitasi, pencemaran udara dan degradasi lahan. Masingmasing komponen pembentuk kualitas lingkungan adalah sebagai berikut:

\subsubsection{Lahan Budidaya}

Lahan budidaya dalam penelitian ini terdiri dari lahan sawah, tegalan dan hutan rakyat. Lahan sawah adalah lahan pertanian yang berpetak-petak dan dibatasi oleh pematang (galengan), saluran untuk menahan/menyalurkan air, yang biasanya ditanami padi sawah tanpa memandang darimana diperoleh atau status lahan tersebut.Data penggunana lahan sawah dibedakan menjadi lahan sawah berpengairan (irigasi) dan lahan sawah tak berpengairan (non) irigasi. Lahan sawah irigasi

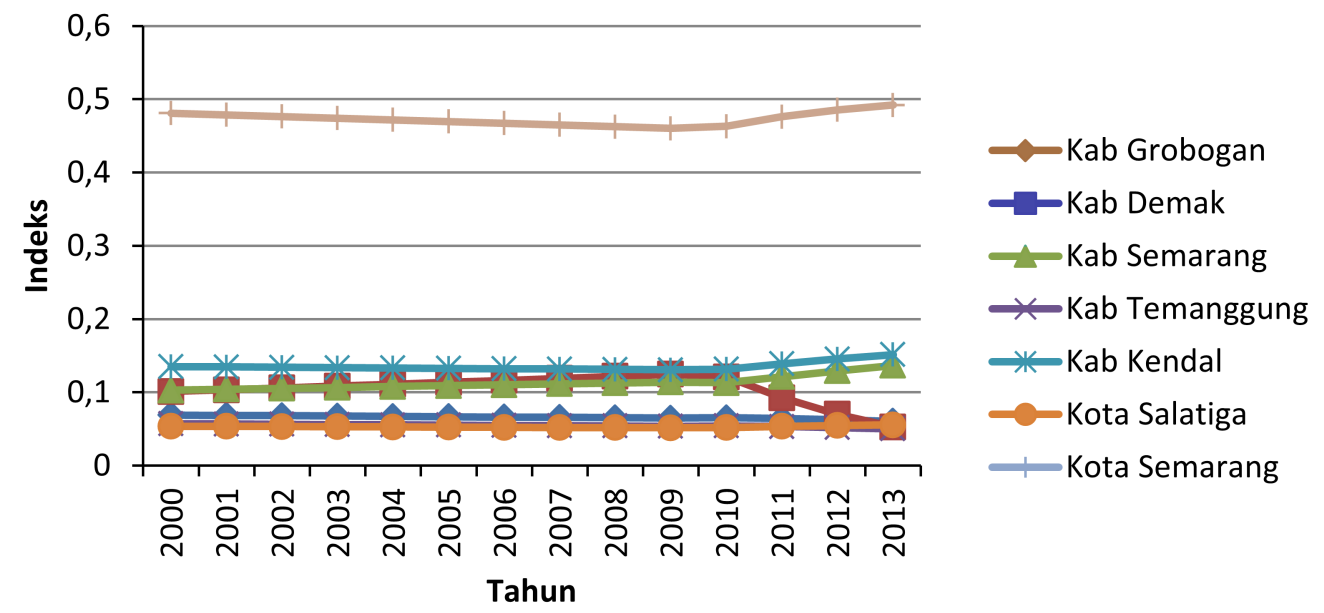

Sumber: BPS, Jawa Tengah dalam Angka

Gambar 1. Indeks Primaci Kabupaten/Kota di Wilayah Aglomerasi Perkotaan Semarang Tahun $2000-2013$ 


\section{Jurnal Ekonomi Pembangunan, 16 (1), Juni 2015, 46-60}

terdiri dari lahan sawah irigasi teknis, irigasi setengah teknis, irigasi sederhana, irigasi desa.

Lahan sawah irigasi teknis adalah lahan sawah yang memperoleh pengairan dari irigasi teknis dimana saluran pemberi terpisah dari saluran pembuang agar penyediaan dan pembagian air ke dalam lahan sawah tersebut dapat sepenuhnya diatur dan diukur dengan mudah. Biasanya lahan sawah irigasi teknis mempunyai jaringan irigasi yang terdiri dari saluran primer dan sekunder serta bangunannya dibangun dan dipelihara oleh Dinas Pekerjaan Umum (PU). Lahan sawah setengah teknis adalah lahan sawah yang memperoleh pengairan dari irigasi setengah teknis. Sama halnya dengan pengairan teknis, tetapi dalam hal ini PU hanya menguasai bangunan penyadap untuk dapat mengatur dan mengukur pemasukan air, sedangkan pada jaringan selanjutnya tidak diukur dan tidak dikuasai oleh PU. Lahan sawah irigasi sederhana adalah lahan sawah yang memperoleh pengairan dari irigasi sederhana yang sebagian jaringannya (bendungannya) dibangun oleh PU. Lahan sawah irigasi desa adalah lahan sawah yang memperoleh pengairan dari sistem pengairan yang dikelola sendiri oleh masyarakat tanpa campur tangan PU.

Lahan sawah non irigasi terdiri dari lahan sawah tadah hujan, lahan sawah pasang surut, lahan sawah lebak, polder, lahan sawah yang sementara tidak diusahakan. Lahan sawah tadah hujan adalah lahan sawah yang pengairannya tergantung pada air hujan. Lahan sawah pasang surut adalah lahan sawah yang pengairannya tergantung pada air sungai yang dipengaruhi oleh pasang surutnya air laut. Lahan sawah lebak adalah lahan sawah yang pengairannya berasal dari reklamasi rawa lebak (bukan pasang surut). Jenis lahan sawah non irigasi lainnya adalah polder. Polder adalah lahan sawah yang terdapat di delta sungai yang pengairannya dipengaruhi oleh air sungai tersebut. Jenis lahan sawah yang termasuk non irigasi lainnya adalah lahan sawah yang sementara tidak diusahakan. Lahan sawah ini sementara tidak diusahakan karena alasan tertentu misalkan tidak ada tenaga dengan kurun waktu lebih dari satu tahun tetapi kurang dari dua tahun. Jika lahan tersebut tidak diusahakan selama lebih dari dua tahun dianggap bukan lahan sawah.

Tanah bukan sawah dapat digunakan sebagai pekarangan/bangunan, tegal/kebun, padang gembala, tambak/kolam, rawa, hutan negara, hutan rakyat, perkebunan negara dan lain-lain (sungai, kuburan). Pekarangan adalah halaman sekitar rumah termasuk yang dipakai untuk rumah/bangunan. Tegalan/kebun adalah lahan bukan sawah yang ditanami tanaman semusim atau tahunan dan terpisah dengan halaman sekitar rumah dan penggunaannya tidak berpindah-pindah. Padang/gembala adalah lahan yang khusus digunakan untuk pengembalaan ternak.

Tambak adalah lahan pertanian yang berpetak-petak dan dibatasi oleh pematang untuk menahan air payau yang biasanya digunakan untuk melakukan pemeliharaan bandeng, udang. Kolam adalah lahan yang dipergunakan untuk pemeliharaan/pembenihan ikan. Rawa adalah lahan yang luas dan tergenang air yang tidak dipergunakan untuk sawah. Hutan negara adalah lahan hutan yang berada di bawah pengawasan Dinas Kehutanan yang berada dalam wilayah kecamatan. Hutan rakyat adalah lahan yang ditumbuhi kayu/ kayuan baik yang tumbuh sendiri maupun sengaja ditanami tetapi tidak termasuk lahan kehutanan. Perkebunan adalah lahan yang ditanami tanaman perkebunan/industri seperti karet, kopi, teh, kelapa baik yang diusahakan oleh rakyat maupun perkebunan besar. Lahan yang dimaksud dalam penelitian ini adalah lahan budidaya atau lahan lahan yang dapat ditanami/diolah yang terdiri dari dari sawah, tegal/kebun dan hutan rakyat.

Pemanfaatan lahan kota yang terus tumbuh akibat tuntutan pembangunan berbagai fasilitas perkotaan dan alih fungsi lahan yang pesat, telah menimbulkan kerusakan lingkungan yang menurunkan daya dukung lahan dalam menopang kehidupan masyarakat perkotaan. Tersedianya lahan budidaya di kota/ perkotaan dapat sebagai penyeimbang lingkungan dalam membantu fungsi hidrologis dalam hal penyerapan air dan mereduksi potensi banjir. Pepohonan melalui perakarannya, mampu 


\section{Jurnal Ekonomi Pembangunan, 16 (1), Juni 2015, 46-60}

meresapkan air ke dalam tanah, sehingga pasokan air dalam tanah (water saving) semakin meningkat dan jumlah aliran limpasan air juga berkurang yang akan mengurangi terjadinya banjir. Lahan budidaya yang tersedia juga mempunyai fungsi kesehatan yang dapat di analogikan sebagai paru-paru kota dan merupakan produsen oksigen yang belum tergantikan fungsinya. Fungsi lain dari adanya lahan budidaya adalah fungsi ekologis yaitu sebagai penjaga kualitas lingkungan kota. Bahkan rindangnya tanaman dengan banyak buah dan biji-bijian merupakan habitat yang baik bagi burung-burung untuk tinggal, sehingga dapat mengundang burung-burung untuk berkembang biak.

Rata-rata rasio lahan budidaya terhadap luas wilayah di Kabupaten/Kota di wilayah aglomerasi perkotaan Semarang tahun 20002013 tertinggi adalah Kabupaten Demak yaitu 89 persen. Kota Semarang, rasio lahan budidaya terhadap luas wilayah paling kecil sebesar 2,9 persen. Luas lahan budidaya Kabupaten Demak tertinggi di wilayah aglomerasi Perkotaan Semarang disebabkan oleh letak geografi Kabupaten Demak yang berada di dataran rendah yaitu 0-100 mdpl sedangkan dilihat dari tekstur tanahnya, wilayah Kabupaten
Demak terdiri atas tekstur tanah halus seluas 49.066 ha dan tekstur tanah sedang seluas 40.677 ha (liat, klei, lempung). Secara administratif luas wilayah Kabupaten Demak 89.743 ha merupakan daerah agraris yang kebanyakan penduduknya hidup dari pertanian dan sebagian besar wilayah Kabupaten Demak terdiri atas lahan sawah yang mencapai luas 50.893 ha (56,71 persen) dan selebihnya lahan kering seluas 38.850 ha (43,29 persen)

Luas lahan budidaya di Kota Semarang terendah di wilayah aglomerasi perkotaan Semarang hal ini disebabkan luas lahan di Kota Semarang sebagian besar berupa lahan bukan sawah yaitu 89,41 persen atau lahan kering sedangkan lahan sawah hanya 10,59 persen. Menurut penggunaannya luas lahan sawah terbesar merupakan lahan sawah tadah hujan sebesar 53,12 persen dan hanya 19,97 persen yang dapat ditanami 2 kali dalam setahun. Lahan kering sebagian besar digunakan untuk tanah pekarangan/tanah untuk bangunan dan halaman sekitarnya sebesar 42,17 persen dari total bukan lahan sawah. Gambaran rasio lahan budidaya terhadap luas wilayah yang ada di Kabupaten/Kota di wilayah aglomerasi perkotaan Semarang dapat dilihat pada Gambar.2. Rata-rata luas lahan budidaya Kabupaten/Kota

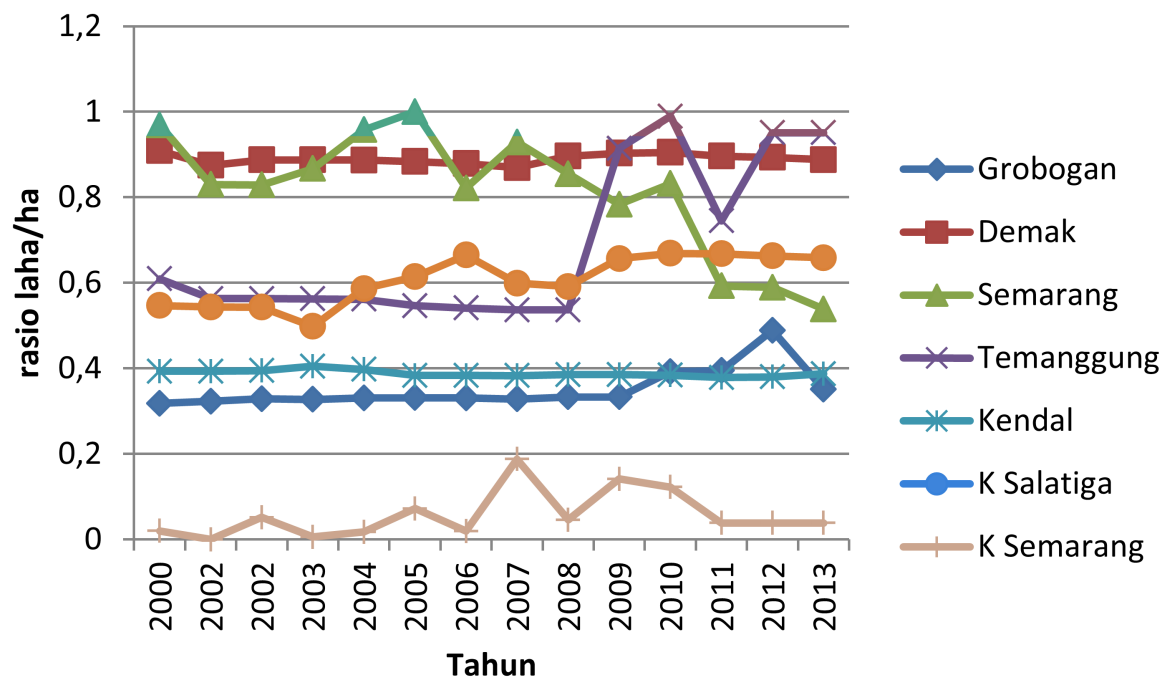

Sumber: BPS, Jawa Tengah dalam Angka, diolah

Gambar 2. Rasio Luas Lahan Budidaya terhadap Luas Wilayah Kabupaten/Kota di Wilayah Perkotaan Semarang Tahun $2000-2013$ 


\section{Jurnal Ekonomi Pembangunan, 16 (1), Juni 2015, 46-60}

di seluruh wilayah aglomerasi perkotaan Semarang $(18,19$ persen). Semua Kabupaten/Kota rata-rata luas lahannya di atas rata-rata luas lahan seluruh wilayah aglomerasi perkotaan Semarang kecuali Kota Semarang.

\subsubsection{Air bersih/kapita}

Air bersih yang dimaksudkan dalam penelitian ini adalah air bersih yang bersumber dari Perusahaan Daerah Air Minum (PDAM) di masing-masing kabupaten/kota di wilayah aglomerasi perkotaan Semarang. Banyaknya air bersih yang dapat diproduksi oleh PDAM dan disalurkan kepada pelanggannya, menunjukkan semakin banyaknya masyarakat yang sudah menggunakan air bersih. Pelanggan PDAM dibedakan berdasarkan golongan tarif yang terdiri dari badan sosial, rumah tangga, niaga, industri, instansi dan daerah khusus seperti pelabuhan, terminal. Di antara golongan tarif, jumlah pelanggan air dari PDAM terbesar adalah rumah tangga. Hal ini berarti produksi air PDAM sebagian besar disalurkan kepada rumah tangga (tempat tinggal), ratarata jumlah produksi air PDAM yang disalurkan kepada pelanggan rumah tangga (tempat tinggal) adalah 50 persen dari seluruh produksi air PDAM untuk kabupaten/kota di wilayah aglomerasi perkotaan Semarang. Air bersih dalam penelitian ini diukur dengan produksi air bersih dari PDAM masing-masing kabupaten/kota dibagi dengan jumlah penduduk.

Rata-rata produksi air bersih/kapita kabupaten/kota di wilayah aglomerasi perkotaan Semarang dari tahun 2000-2013 secara rinci dapat dilihat pada Gambar 3. Kabupaten/kota di wilayah aglomerasi perkotaan Semarang yang paling tinggi rata-rata produksi air bersih/ kapitanya dari tahun 2000-2013 adalah Kota Semarang (61,53 $\mathrm{m}^{3} /$ kapita/tahun) dan terendah adalah Kabupaten Gro bogan $\left(6,17 \mathrm{~m}^{3 /}\right.$ kapita/tahun). Rata-rata produksi air bersih Kabupaten/Kota di seluruh wilayah aglomerasi perkotaan Semarang $\left(33,85 \mathrm{~m}^{3} / \mathrm{kap} / \mathrm{tahun}\right)$. Kabupaten/Kota yang rata-rata produksi air bersihnya di atas rata-rata produksi air bersih seluruh wilayah aglomerasi perkotaan Semarang adalah Kota Salatiga dan Kota Semarang lainnya di bawah rata-rata. Dengan demikian dapat disimpulkan sebagian besar Kabupaten/ Kota di wilayah aglomerasi perkotaan Semarang produksi air bersihnya masih kurang.

Persoalan yang sangat penting dan harus ada solusi pemecahannya di setiap PDAM kabupaten/kota baik di wilayah perkotaan Semarang adalah masih banyaknya air yang tidak tersalurkan sesuai dengan jumlah pro-

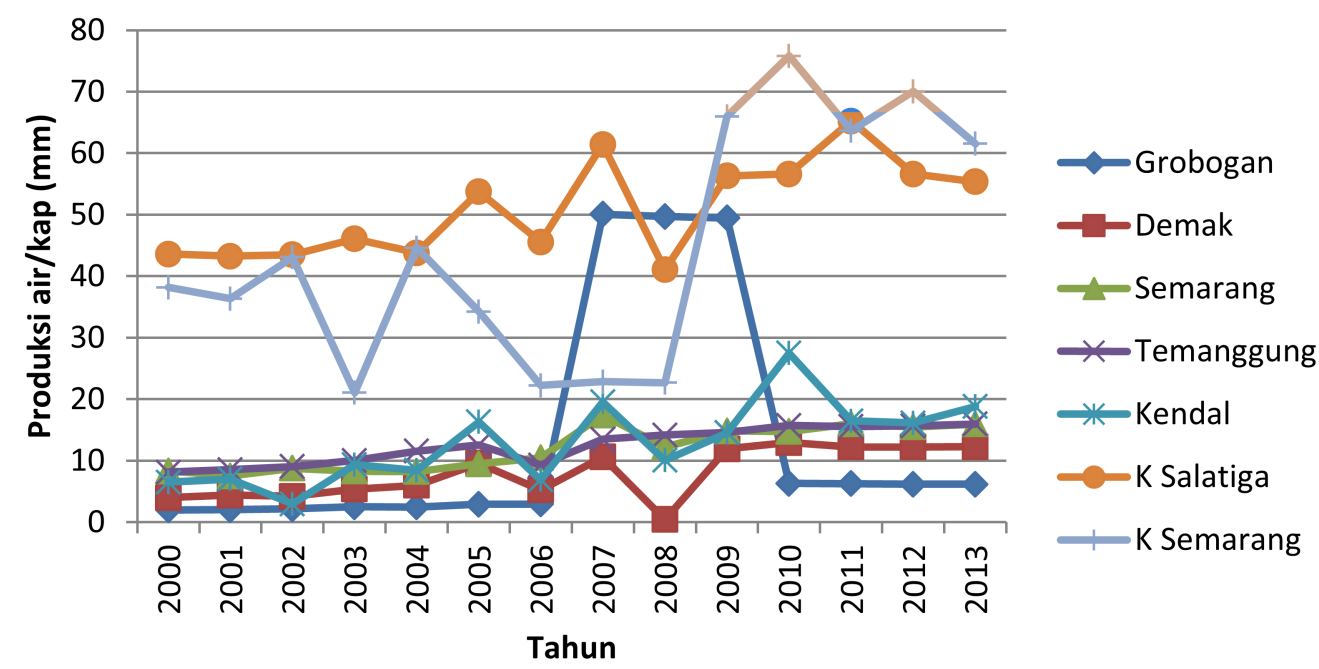

Sumber: BPS, Jawa Tengah dan DIY dalam Angka, diolah

Gambar 3. Produksi air bersih Kabupaten/Kota di Wilayah Perkotaan Semarang Tahun 2000 - 2013 


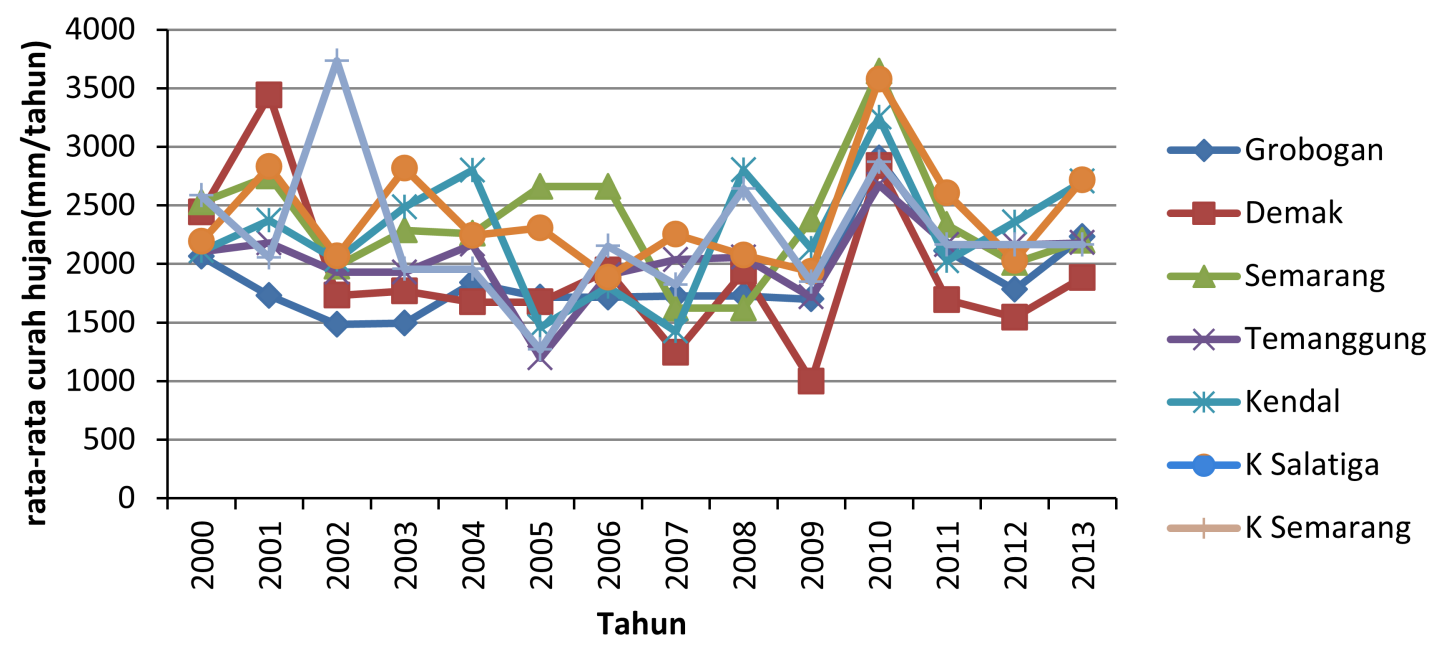

Sumber : BPS, Jawa Tengah dalam Angka, diolah

Gambar 4. Rata-Rata Curah Hujan Kabupaten/Kota di Wilayah Perkotaan Semarang Tahun 2000 - 2013

duksi karena hilang/susut, rata-rata sebesar 20 persen. Hilangnya air/susutnya air jika dapat diminimalkan akan menambah jumlah air bersih yang dapat disalurkan.

\subsubsection{Curah Hujan}

Curah hujan dalam penelitian ini diukur dengan rata-rata curah hujan per tahun di kabupaten/kota di wilayah aglomerasisi perkotaan Semarang. Ada beberapa faktor yang mempengaruhi curah hujan yaitu: Faktor garis lintang, ketinggian tempat, jarak dari sumber air (penguapan), arah angin, hubungan dengan deretan pegunungan, perbedaan suhu tanah (daratan) dan lautan dan faktor luas daratan. Rata-rata curah hujan Kabupaten/Kota di wilayah aglomerasi perkotaan Semarang dari tahun 2000-2013 secara rinci dapat dilihat pada Gambar 4. Kota Salatiga adalah kabupaten dengan rata-rata curah hujan tertinggi di wilayah aglomerasi perkotaan Semarang. Ratarata curah hujan di Kota Salatiga sebesar $2454,5 \mathrm{~mm} /$ tahun atau $204,54 \mathrm{~mm} / \mathrm{bulan}$. Sebagian besar wilayah Kabupaten Semarang berada pada daerah dataran tinggi yang relatif sejuk, namun ditinjau dari intensitas curah hujan tergolong sedang. Rata-rata curah hujan Kabupaten/Kota di seluruh wilayah aglomerasi perkotaan Semarang adalah $2261 \mathrm{~mm} /$ tahun.

Rata-rata indeks kualitas lingkungan dihitung dari masing-masing indeks tunggal dari indikator kualitas lingkungan yaitu luas lahan budidaya, air bersih/kapita dan curah hujan di wilayah aglomerasi perkotaan Semarang dari tahun 2000-2013. Rata-rata indeks kualitas lingkungan di wilayah aglomerasi perkotaan Semarang tertinggi adalah Kota Salatiga sebesar 0,485 dan terendah adalah Kota Semarang sebesar 0,31. Kabupaten/Kota yang menempati urutan kedua adalah Kabupaten Temanggung dan ketiga adalah Kabupaten Semarang. Melihat urutan satu sampai ketiga dalam hal kualitas lingkungan, secara topografi ketiga kabupaten/kota tersebut terletak di dataran tinggi yang relatif beriklim sejuk. Gambaran indeks kualitas lingkungan Kabupaten/Kota di wilayah aglomerasi perkotaan Semarang dapat dilihat pada Gambar 5. Ratarata indeks kualitas lingkungan Kabupaten/ Kota di seluruh wilayah aglomerasi perkotaan Semarang adalah 0,33. Kabupaten/Kota yang rata-rata indeks kualitas lingkungan di atas rata-rata indeks kualitas lingkungan seluruh wilayah aglomerasi perkotaan Semarang kecuali Kota Semarang. 
Jurnal Ekonomi Pembangunan, 16 (1), Juni 2015, 46-60

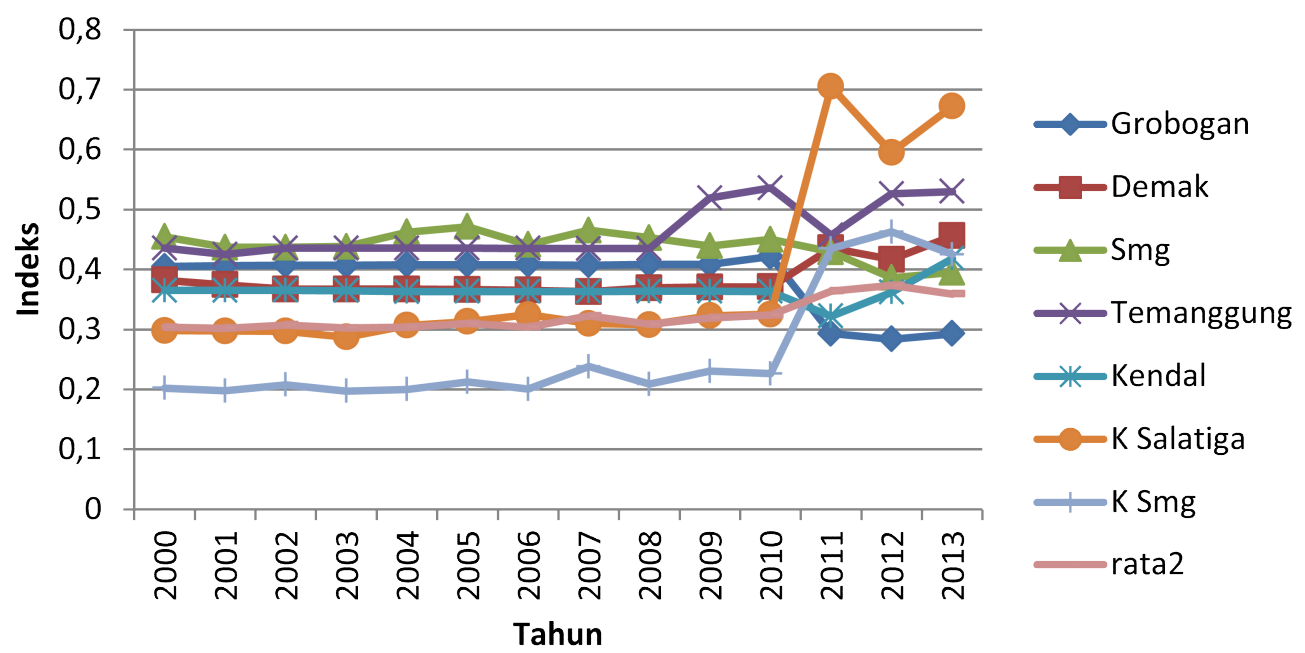

Sumber: BPS, Jawa Tengah dalam Angka, diolah

Gambar 5. Indeks Kualitas Lingkungan Kabupaten/Kota di Wilayah Perkotaan Semarang Tahun $2000-2013$

\subsection{Hubungan Kausalitas Antara Konsentrasi Perkotaan dan Kualitas Lingkungan}

Untuk menguji hubungan kausalitas antara konsentrasi perkotaan dan lingkungan digunakan uji kausalitas Granger. Ada beberapa tahapan dan persyaratan yang dilakukan untuk menggunakan alat uji tersebut. Pengujian tersebut berkaitan erat dengan pengujian terhadap kemungkinan adanya hubungan keseimbangan jangka panjang antara variabel-variabel ekonomi.

Berkaitan dengan isu tersebut, pengujian terhadap perilaku data runtun waktu (time series) atau integrasinya dapat dipandang sebagai uji prasyarat bagi digunakannya pendekatan model dinamis.Untuk itu, pertama-tama harus diamati perilaku data runtun waktu yang akan digunakan stasioner atau tidak. Data stationer pada dasarnya tidak memiliki variasi yang terlalu besar selama periode obsvasi dan memiliki kecenderungan untuk mendekati nilai rata-ratanya. Apabila data tidak stasioner, maka regresi yang menggunakan data tersebut akan memiliki $\mathrm{R}^{2}$ yang relatif tinggi namun memiliki nilai statistik Durbin Watson yang rendah. Hal tersebut memberikan indikasi bahwa regresi yang dihasilkan adalah lancung (spurious regression). Akibat yang ditimbulkan oleh regresi lancung antara lain koefisien regresi penaksir tidak efisien, peramalan berdasarkan regresi tersebut akan meleset dan uji baku yang umum untuk koefisien regresi terkait menjadi tidak sahih (invalid). Selanjutnya, apabila diyakini bahwa variabel-variabel yang diamati mempunyai derajat integrasi yang sama, maka dapat diuji residual variabel yang dihasilkan stationer atau tidak.

\subsubsection{Uji Akar-Akar Unit}

Uji akar-akar unit dipandang sebagai uji stasioneritas, karena pada prinsipnya uji ini dimaksudkan untuk mengamati apakah koefisien tertentu dari model stationer atau tidak. Indikator yang digunakan untuk mengukur variabel konsentrasi perkotaan kota adalah indeks primasi dari tahun 2000-2013 (IP). Pengukuran kualitas lingkungan (EQI)seperti dijelaskan pada metode penelitian diukur dengan tiga komponen yaitu LNB, AB dan CH. Tahapan awal adalah uji akar-akar unit. Dengan menggunakan program Eviews 8, Secara ringkas hasil uji akar-akar unit bisa dilihat pada Tabel 3. 


\section{Jurnal Ekonomi Pembangunan, 16 (1), Juni 2015, 46-60}

Tabel 3. Hasil Uji Akar-Akar Unit Variabel Konsentrasi perkotaan (IP) dan Kualitas lingkungan (EQI)

\begin{tabular}{clc}
\hline Variabel & Nilai DF & Nilai ADF \\
\hline EQI & $-3,647772 *$ & $-3,65026^{* *}$ \\
IP & $-0,734673$ & $-1,629155$ \\
\hline
\end{tabular}

* sig pada $\alpha=1 \%$

** sig pada $\alpha=5 \%$

Uji akar-akar unit menggunakan uji Dickey dan Fuller, kemudian dilihat dari nilai statistik DF (Dickey-Fuller) dan ADF (Augmented Dickey-Fuller). Tabel 3 memperlihatkan hasil uji akar-akar unit untuk variabel lingkungan nilai statistik baik nilai $\mathrm{DF}$ maupun nilai $\mathrm{ADF}$ signifikan artinya data tersebut sudah stasioner, tetapi untuk varibel IP belum signifikan artinya belum stationer sehingga harus dilakukan uji tahap berikutnya yaitu uji integrasi.

\subsubsection{Uji Integrasi}

Uji integrasi dilakukan terhadap variabel IP yang pada uji akar unit belum stationer. Dengan menggunakan program Eviews 8 hasil uji integrasi pertama secara ringkasnya hasil uji integrasi dapat dilihat pada Tabel 4.

Hasil uji integrasi pertama pada Tabel 4, menunjukkan bahwa variabel IP nilai statistik DF dan ADF sudah signifikan yang berarti sudah stasioner, selanjutnya dilakukan uji kointegrasi.

Tabel 4. Hasil Uji Integrasi Pertama Variabel Pertumbuhan Kota (IP)

\begin{tabular}{|c|c|c|}
\hline Variabel & Nilai DF & Nilai ADF \\
\hline IP & $-9,826227^{*}$ & $-9,889137^{*}$ \\
\hline
\end{tabular}

* sig pada $\alpha=1 \%$

\subsubsection{Uji Kointegrasi}

Untuk dapat mengetahui apakah suatu model empiris mempunyai hubungan kointegrasi, maka ada tiga nilai yang perlu diperhatikan, yaitu nilai statistik CRDW (Cointegration-
Regression Durbin Watson), DF ( Dickey Fuller) dan ADF (Augmented Dickey Fuller). Ketiga nilai tersebut ditaksir dengan regresi kointegrasi dengan metode kuadrat terkecil (Ordinary Least Square). Dengan menggunakan program Eviews 8 Secara lengkap hasil uji kointegrasi untuk ringkasnya dapat dilihat pada Tabel 5 .

Tabel 5. Hasil Uji Kointegrasi Kausalitas Variabel Pertumbuhan Kota (IP) dan Lingkungan (EQI)

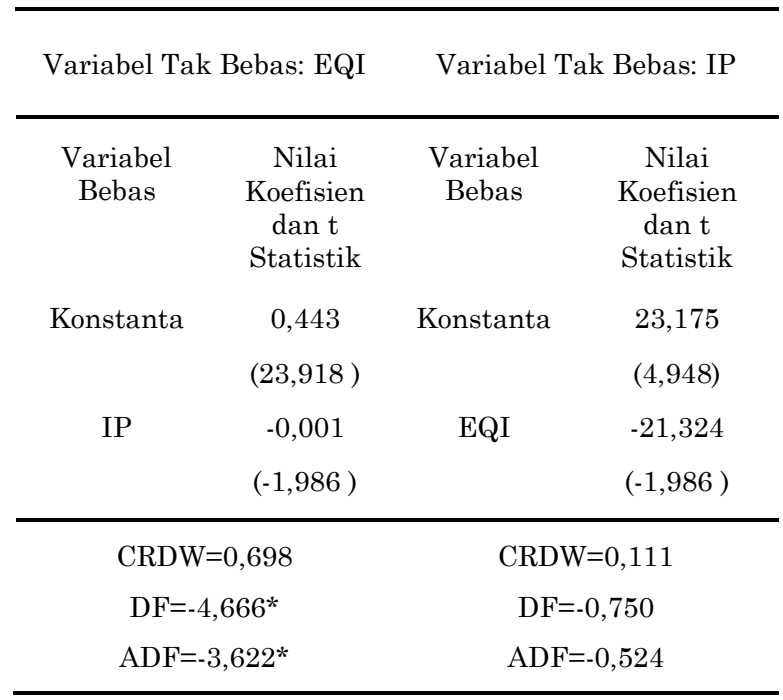

Sumber: data diolah

Berdasarkan Tabel 5, dapat disimpulkan bahwa dengan $\alpha=5 \%$ residual persamaan kointegrasi untuk variabel IP sebagai variabel tak bebas tidak stationer pada derajat 0 yang ditandai dengan tidak signifikansinya nilai CRDW, DF dan ADF secara. Dengan demikian antara IP sebagai indikator pertumbuhan kota dan lingkungan tidak ditemukan adanya pola kausalitas, artinya semakin tinggi atau semakin baiknya kualitas lingkungan tidak menyebabkan pertumbuhan kota meningkat atau sebaliknya semakin tinggi pertumbuhan kota suatu wilayah tidak menyebabkan lingkungan semakin tinggi atau baik. Untuk persamaan yang variabel tak bebasnya EQI dan bebasnya konsentrasi perkotaan nilai statistik CRDWnya signifikan. Dengan demikian antara lingkungan dan konsentrasi perkotaan ditemukan 


\section{Jurnal Ekonomi Pembangunan, 16 (1), Juni 2015, 46-60}

adanya pola kausalitas searah, artinya semakin tinggi konsentrasi perkotaan akan berpengaruh terhadap lingkungan.

\subsubsection{Uji Kausalitas Granger}

Setelah uji akar unit, uji integrasi dan uji kointegrasi, tahapan yang terakhir adalah uji kausalitas Granger. Dalam pengujian ini, panjangnya kelambanan (lag) ditetapkan masingmasing sebesar 2. Penggunaan uji kausalitas Granger dapat mengetahui hubungan kausal dari dua variabel, apakah hubungan yang timbal balik, searah atau bahkan tidak ditemukan pola hubungan kausal dalam konteks jangka pendek. Dengan menggunakan porogram Eviews 8, hasil uji kausalitas Granger dapat dilihat pada Tabel 6 .

Berdasarkan Tabel 6, dapat disimpulkan bahwa tidak ada pola hubungan kausalitas timbal balik antara konsentrasi perkotaan dan lingkungan. Hal ini ditunjukkan dengan hasil uji kausalitas Granger dengan null hypothesis antara pertumbuhan kota dan lingkungan dengan nilai prob 0,2109. Namun dari uji Kointegrasi ditemukan hubungan searah antara pertumbuhan kota dan lingkungan. Pertumbuhan kota berdampak terhadap lingkungan.

Hasil penelitian ini konsisten dengan penelitian Li, S dan Yong Ma (2014), Lakshmana, C.M (2013), Coles et al. (2010), Jiang dan Harde (2009) dan Cho et al. (2007) yang menjelaskan ada hubungan antara konsentrasi perkotaan yang diukur dengan semakin bertambahnya jumlah penduduk perkotaan dengan lingkungan. Pada umumnya jumlah penduduk yang semakin meningkat, meningkat pula sumber daya yang dibutuhkan misalnya pemukiman, alat transpotasi. Berbicara pemukiman tidak lepas dengan kebutuhan lahan. Sementara lahan jumlahnya terbatas dibandingkan kepentingan terhadap lahan. Akibatnya banyak alih fungsi lahan yang semula lahan dimanfaatkan sebagai lahan pertanian berubah menjadi pemukiman. Keberadaan lahan pertanian sebagai salah satu indikator lingkungan yang hijau sudah mulai berkurang. Belum lagi alih fungsi dari pertanian ke sektor industri.

Hasil penelitian ini mengharuskan pihak pemerintah kabupaten/kota memiliki perencanaan perkotaan yang matang terutama berkaitan dengan lingkungan. Meningkatnya jumlah penduduk di satu sisi membutuhkan tambahan sarana dan prasarana yang harus disediakan namun di sisi lain berdampak negatif terhadap lingkungan. Regulasi yang dilakukan pemerintah dapat dimulai selektif dalam mengeluarkan ijin bangunan, baik secara perorangan maupun pengembang. Penambahan alat transportasi harus sudah mulai dipikirkan terhadap bahan bakar minyak yang digunakan agar tidak menimbulkan masalah lingkungan.

\section{Simpulan}

Berdasarkan hasil penelitian dan pembahasan dapat disimpulkan sebagai berikut: konsentrasi

Tabel 6. Hasil Uji Kausalitas Granger Variabel Konsentrasi Perkotaan (IP) dan Lingkungan (EQI)

Pairwise Granger Causality Tests

Date: 06/30/15 Time: 05:54

Sample: 198

Lags: 2

Null Hypothesis:

IP does not Granger Cause EQI

EQI does not Granger Cause IP
Obs

F-Statistic

Prob.

Sumber: Data diolah 


\section{Jurnal Ekonomi Pembangunan, 16 (1), Juni 2015, 46-60}

perkotaan di wilayah aglomerasi perkotaan Semarang selama periode tahun 2000-2013 masih cenderung memusat di kota inti (core) yaitu di Kota semarang. Hal ini terlihat pada hasil penghitungan indeks primasi. Kondisi lingkungan di daerah kota pinggiran (zone) yang bukan kota inti di wilayah aglomerasi perkotaan Semarang jauh lebih baik dibandingkan kota inti. Hal ini terlihat dari angka indeks lingkungan. Uji Kausalitas Granger menunjukkan tidak ada pola hubungan kausalitas timbal balik antara konsentrasi perkotaan dan lingkungan yang ada hubungan yang searah antara konsentrasi perkotaan dan lingkungan. Hal ini berarti semakin tinggi konsentrasi perkotaan semakin turun kualitas lingkungan. Uji Kausalitas Granger hanya digunakan sebagai analisis jangka pendek, untuk keperluan analisis jangka panjang dapat digunakan alat analisis lainnya seperti uji kausalitas model koreksi kesalahan baku yang tidak memerlukan persyaratan data stasioner bagi data time series.

\section{Daftar Pustaka}

Ades, A.F., and E.L,Glaeser. 1995. Trade and circuses: explaining urban giants. Quarterly Journal of Economics, Vol.110: 195227

Adita, C.B.R dan Ratni J.A.R, Nanik. 2012. Tingkat kemampuan penyerapan tanaman hias dalam menurunkan polutan karbon monoksida. Jurnal Ilmiah Teknik Lingkungan, Vol.4 (1): 54-60.

an Dijk and Mingshun. 2005. Sustainability indices as a tool for urban managers, Evidence from four medium-sized Chinese Cities, Environmental Impact Assessment Review Journal, Vol 25: 667-688

Badan Pusat Statistik. 2011. Statistik Indonesia, www.datasatatistik-indonesia.com/ index2.php?option=com, diunduh tanggal 1 Agustus 2014

Badan Pusat Statistik. Jawa Tengah dalam Angka Tahun 1999-2014

Bourne, L.S. 1986. Comparing urban system: measurement criteria and empirical eval- uations. Canadian Journal of Regional Science, Vol IX (1): 89-101

Cho, S. et.al. 2007. The impact of an urban growth boundary on land development in Knox County, Tennessee: A Comparison of two stage probit least squares and multilayer neural network models. Journal of Agricultural and Applied Economic, Vol.39 (3): 701-717.

Coles, J.F., et.al. 2010. Judging a Brook by its Cover: The relation between ecological condition of a stream and urban land cover in New England. Northeastern, Naturalist, Vol.17 (1):29-48.

Cropper, M and Charles Griffiths. 1994. The interaction of population growth and environmental quality. American Economic Review, Vol 84: 250-254.

Dasgupta. 1995. Population, poverty and the local environment. Scientific American (February): 40-45.

Henderson, J.V. 2002. Urbanization in developing countries. The World Bank Research Observer, Vol 17 (1): 89-112.

http://www.feunpak.web.id/artikel-fe/111pohon-penyerap-co2-pencemar-penghasiloksigen-dan-penyimpan-karbon. Diunduh tanggal 29 Agustus 2013.

Jiang and Hardee. 2009. How do recent population trends matter to climate change. Working Paper Population Action International, April 2009.

Kementerian Negara Lingkungan Hidup Republik Indonesia. 2010. Status lingkungan hidup Indonesia.

Kementerian Negara Lingkungan Hidup Republik Indonesia. 2012. Indeks kualitas lingkungan hidup 2011, Jakarta: KLH.

Kuncoro, M. 2001. Metode kuantitatif: teori dan aplikasi untuk bisnis dan Ekonomi. Yogyakarta:UPP AMP YKPN.

Kuncoro, M. 2003. Metode riset untuk bisnis \& ekonomi: bagaimana meneliti \& menulis tesis?. Jakarta: Erlangga.

Laksmana, C.M. 2013. Population, development, and environment in India, Chinese 


\section{Jurnal Ekonomi Pembangunan, 16 (1), Juni 2015, 46-60}

Journal of Population Resources and Environment, Vol.11 (4): 367-374.

Lee and Huang. 2007. Sustainability index for Taipei. Environmental Impact Assesment Review, Vol 27: 505-521.

Li, Shushu and Yong Ma. 2014. Urbanization, economic development and environmental change. Sustainability, Vol 6: 5143-5161.

McGranahan, D.A., Wojan, T.R., and Lambert, D.M. 2011. The rural growth trifecta: outdoor amanities, creative class and entrepreneurial context. Jounal of Economic Geography, Vol.11: 529-557.

Moomaw, R.L., and A.M Shatter. 1996. Urbanization and Economic development: A bias toward a large city. Journal of Urban Economics, Vol 40: 13-37.

Moomaw, R.L., and M. A, Alwosabi. 2004. An Empirical analysis of competing explanations of urban primacy evidence from Asia and Americas. Regional Science, Vol 38: 149-171.

Moomaw, R.L., and M. A, Alwosabi. 2007. Urban primacy, gigantism, and international trade: evidence from Asia and The Americas. Journal of Economic Integration, Vol 22 (2): 439-460.

Pujiati, Amin dan J.J Sarungu. 2012. Aspek lingkungan dalam pertumbuhan kota di wilayah aglomerasi perkotaan Semarang dan Daerah Istimewa Yogyakarta. Kinerja: Jurnal Bisnis dan Ekonomi, Vol 16 (1): 1-12.

Qasim, M, Anees, M.M, Ghani, M.U, Malik, J, Khalid, Mand Bashir A, 2014, Environment degradation cause by urbanization in Pakistan (A Review Paper). Bulletin of Energy Economics, Vol.2 (3):62-71.

Rohman, A.S. 2009. Pohon: Penyerap $\mathrm{CO}_{2} \mathrm{Pen}-$ cemar, Penghasil Oksigen dan Penyimpan Karbon.
Salenuss. 2009. Beberapa karakteristik umum pertumbuhan empat kota besar di Maluku sebelum pemekaran (Tahun 1985-1995), Jurnal Lembaga Ilmu Pengetahuan Indonesia (LIPI), Vol.III (1): 39 50 .

Saputra, I.D. 2008. Fluktuasi indeks polusi udara di DKI Jakarta (Studi Kasus: Tahun 2001-2006). Skripsi, Jakarta, FMIPA, Universitas Indonesia.

Setiyanto, A., Nurmanaf, A.R., Soelaeman, Y., Mayrowani, H., dan Dermoredjo, S.K. 2003. Nilai ekonomi fungsi lahan sawah untuk pengendalian pencemaran udara: studi kasus di DAS Citarum, Jawa Barat, Prosiding Seminar Nasional Multifungsi dan Konversi Lahan Pertanian.

Sherbinin. 2003. The role of sustainability indicators as a tool for assecing territorial environmental competitiveness, Presented: International Forum for Rural Development, 4-6 November 2003, Brazil.

The Economist Intelligence Unit. 2011. Asian Green City, Research Report.

Thomas, V and Tamara Belt. 1997. Growth and environment; allies or foes, Finance and Development, Vol 34 (Juni): 22-24.

Todaro, M.P., and Smith, S.C., 2006, Economic development, ninth edition, Pearson Education, Inc. Munandar, H (penterjemah), Pembangunan Ekonomi, Edisi kesembilan, Jakarta: Erlangga.

Wahyudi. 2009. Ketersediaan alokasi ruang terbuka hijau kota pada ordo kota I Kabupaten Kudus, Tesis S2 (tidak dipublikasikan), Semarang, Program, Magister Ilmu Lingkungan, Universitas Diponegoro.

www.memlh.go.id/publikasi/buku/HLH\%2 0210/HLH2010/Pdf. Diunduh tanggal 29 September 2011. 
Avalaible online at http://journals.ums.ac.id

Jurnal Ekonomi Pembangunan, 16 (1), Juni 2015, 46-60

\section{Lampiran}

Indeks Primacy Kabupaten/Kota di Wilayah Aglomerasi Perkotaan Semarang Tahun 2000 - 2013

\begin{tabular}{|c|c|c|c|c|c|c|c|c|c|c|c|c|c|c|c|}
\hline Kab/kota & 2000 & 2001 & 2002 & 2003 & 2004 & 2005 & 2006 & 2007 & 2008 & 2009 & 2010 & 2011 & 2012 & 2013 & Rata-rata \\
\hline Grobogan & 0,069 & 0,068 & 0,068 & 0,068 & 0,067 & 0,067 & 0,066 & 0,066 & 0,065 & 0,065 & 0,065 & 0,064 & 0,063 & 0,061 & 0,065 \\
\hline Demak & 101 & 0,104 & 0,106 & 0,109 & 0,111 & 0,114 & 0,116 & 0,119 & 0,122 & 0,125 & 0,121 & 0,093 & 0,070 & 0,053 & 0,077 \\
\hline Semarang & 0,103 & 0,104 & 0,105 & 0,107 & 0,108 & 0,109 & 0,110 & 0,112 & 0,113 & 0,114 & 0,113 & 0,121 & 0,129 & 137 & 0,120 \\
\hline Tmanggung & 0,057 & 0,057 & 0,056 & 0,056 & 0,056 & 0,055 & 0,055 & 0,055 & 0,054 & 0,054 & 0,054 & 0,053 & 0,052 & 0,050 & 0,052 \\
\hline Kendal & 0,135 & 0,135 & 0,134 & 0,134 & 0,133 & 0,133 & 0,132 & 0,132 & 0,131 & 0,131 & 0,132 & 0,139 & 0,146 & 0,152 & 0,143 \\
\hline K Salatiga & 0,054 & 0,054 & 0,053 & 0,053 & 0,053 & 0,053 & 0,052 & 0,052 & 0,052 & 0,052 & 0,052 & 0,054 & 0,055 & 0,056 & 0,055 \\
\hline K Smg & 0,481 & 0,479 & 0,477 & 0,474 & 0,472 & 0,470 & 0,467 & 0,465 & 0,463 & 0,460 & 0,463 & 0,476 & 0,486 & 0,492 & 0,487 \\
\hline Rata-rata & 0,275 & 0,274 & 0,272 & 0,271 & 0,270 & 0,269 & 0,269 & 0,265 & 0,264 & 0,263 & 0,264 & 0,270 & 0,274 & 0,276 & 0,276 \\
\hline
\end{tabular}

Sumber: BPS, Jawa Tengah dalam Angka, diolah 